\title{
Attenuation of allergic airway inflammation and hyperresponsiveness in a murine model of asthma by silver nanoparticles
}

This article was published in the following Dove Press journal:

International Journal of Nanomedicine

10 July 2010

Number of times this article has been viewed

\author{
Hee Sun Park ${ }^{1, *}$ \\ Keun Hwa Kim ${ }^{1, *}$ \\ Sunhyae Jang' \\ Ji Won Park' \\ Hye Rim Cha' \\ Jeong Eun Lee' \\ Ju Ock Kim' \\ Sun Young Kim' \\ Choong Sik Lee ${ }^{2}$ \\ Joo Pyung $\mathrm{Kim}^{3}$ \\ Sung Soo Jung' \\ 'Division of Pulmonology, Allergy and \\ Critical Care Medicine, Department \\ of Internal Medicine, Chungnam \\ National University Medical School, \\ Daejeon, Korea; ${ }^{2}$ Department of \\ Pathology, Chungnam National \\ University Medical School, Daejeon, \\ Korea; ${ }^{3}$ Nanochemical Incorporation, \\ *Contributed equally to this work
}

\begin{abstract}
The use of silver in the past demonstrated the certain antimicrobial activity, though this has been replaced by other treatments. However, nanotechnology has provided a way of producing pure silver nanoparticles, and it shows cytoprotective activities and possible pro-healing properties. But, the mechanism of silver nanoparticles remains unknown. This study was aimed to investigate the effects of silver nanoparticles on bronchial inflammation and hyperresponsiveness. We used ovalbumin (OVA)-inhaled female C57BL/6 mice to evaluate the roles of silver nanoparticles and the related molecular mechanisms in allergic airway disease. In this study with an OVA-induced murine model of allergic airway disease, we found that the increased inflammatory cells, airway hyperresponsiveness, increased levels of IL-4, IL-5, and IL-13, and the increased NF- $\mathrm{KB}$ levels in lungs after OVA inhalation were significantly reduced by the administration of silver nanoparticles. In addition, we have also found that the increased intracellular reactive oxygen species (ROS) levels in bronchoalveolar lavage fluid after OVA inhalation were decreased by the administration of silver nanoparticles. These results indicate that silver nanoparticles may attenuate antigen-induced airway inflammation and hyperresponsiveness. And antioxidant effect of silver nanoparticles could be one of the molecular bases in the murine model of asthma. These findings may provide a potential molecular mechanism of silver nanoparticles in preventing or treating asthma.
\end{abstract}

Keywords: allergic airway disease, NF- $\mathrm{KB}$, oxidative stress, silver nanoparticles

\section{Introduction}

Nanomaterials are a diverse class of small-scale $(<100 \mathrm{~nm})$ substances, formed by molecular-level engineering and designed to offer unique mechanical, optical, electrical, and magnetic properties. ${ }^{1}$ Recently, much effort has been devoted to the development of biomedical applications for nanoparticles (NPs). NPs are also being examined for potential medical applications, such as drug delivery, because they are able to pass readily through cell membranes. ${ }^{2}$ Metal NPs have been attracting increasing attention due to their important applications in a number of subject areas, such as catalysis and nanoscale electronics. ${ }^{3-6}$ While significant advances in biological labeling have been made, few therapeutic applications for metal NPs have been reported in the literature. ${ }^{7,8}$ Some noble metal NPs are catalysts for reduction reactions; thus, they may be usable as antioxidants, reducing reactive oxygen species (ROS) in the living body. ${ }^{9-11}$ Another candidate material for NPs is silver, which has long been known as a strong antimicrobial agent and disinfectant, which may be due to the blockage of the respiratory enzyme pathways, alterations in microbial DNA, and cell wall modification. ${ }^{12}$ Silver has been used for centuries to prevent and treat a variety
Correspondence: Sung Soo Jung Department of Internal Medicine, Chungnam National University Hospital and Cancer Research Institute, Daesadong, Daejeon $301-721$, South Korea Tel +82-42-280-8446 Fax +82-42-257-5753

Email drpark@cnu.ac.kr 
of diseases, including its use in pleurodesis, cauterization, and healing of skin wounds. ${ }^{13,14}$ The use of silver in the past has been restrained by difficulties in the production of pure silver compounds, thereby increasing potential side effects. Nanotechnology has provided a way of producing pure silver NPs. Some studies of silver NPs have demonstrated that they exhibit cytoprotective activities toward HIV-1-infected cells and anti-inflammatory effects, through cytokine modulation upon topical application. ${ }^{15-17}$ However, the exact mechanism of their anti-inflammatory effects is not fully understood.

Widespread application of nanomaterials holds enormous potential for safe human exposure and environmental release. Elemental silver occurs naturally. It is considered non-toxic, non-allergic, is not cumulative, and is not known to harm either wildlife or the environment. Products made with silver nanoparticles have been approved by a range of authorities, including the US FDA, US EPA, the SIAA of Japan, Korea's Testing and Research Institute for Chemical Industry and the FITI Testing and Research Institute. Many consumer goods (eg, toys, baby pacifiers, clothing, food storage containers, face masks, HEPA filters, laundry detergent) already incorporate silver NPs for their antimicrobial properties. While ingestion and skin penetration are potential exposure routes for engineered nanomaterials, the inhalation route for airborne nanomaterials has perhaps received the most attention. ${ }^{18,19}$

In the present study, we used a mouse model of allergic airway disease to evaluate the effect of silver NP inhalation on airway hyperresponsiveness and inflammation and to investigate the related molecular mechanisms.

\section{Material and methods}

\section{Transmission electron microscope (TEM) imaging of silver NPs}

For morphological studies of silver NPs, we had assistance from the National Nanofab Center, Korea Advanced Institute of Science and Technology in Daejeon. To enable the characterization of the samples using TEM imaging with a reasonable resolution, a silver NP solution was diluted in alcohol and was dispersed evenly for prevention of aggregating particles and elimination of water. It was coated with mesh grid during imaging. The fine structure and particle size images of the silver NPs powder were obtained using a TEM (JEM-3020, 300 kV, JEOL, Japan).

\section{Animals and experimental protocol}

Female C57BL/6 mice, 8-10 weeks of age and free of murine specific pathogens, were obtained from Damul Science Inc. (Daejeon, South Korea) and were maintained under standard laboratory conditions in a pathogen-free cage, with ad libitum access to food and water. All animal experiments in this study were conducted in accordance with the guidelines of the Institutional Animal Care and Use Committee of the Chungnam National University Medical School.

Mice were sensitized on days 1 and 14 via an intraperitoneal (ip) injection of $20 \mu \mathrm{g}$ of ovalbumin (OVA) (Sigma-Aldrich, St. Louis, MO, USA) emulsified in $1 \mathrm{mg}$ of aluminum hydroxide (Pierce Chemical Co., Rockford, IL, USA) in a total volume of $100 \mu \mathrm{L}$. On days 21-23 after the initial sensitization, the mice were challenged for 30 min with an aerosol of 3\% (weight/volume) OVA in saline (or saline alone as a control) using an ultrasonic nebulizer (NE-U12, Omron, Japan). Bronchoalveolar lavage (BAL) was performed 72 hours after the final challenge. At the time of lavage, the mice (8 per group) were sacrificed with an overdose of pentobarbital sodium (100 mg/kg body weight, ip). The chest cavity was exposed to allow for expansion, after which the trachea was carefully intubated and the catheter was secured with ligatures. Pre-warmed $0.9 \% \mathrm{NaCl}$ solution was slowly infused into the lungs and withdrawn. The aliquots were pooled and kept at $4^{\circ} \mathrm{C}$. A part of each pool was centrifuged, and the supernatant was kept at $-70^{\circ} \mathrm{C}$ until use. Total cell numbers were counted using a hemocytometer. Smears of BAL cells were prepared using a cytospin (Cellspin; Hanil Science Industrial Co, Ltd, Inchon, South Korea). To examine cell differentials, the smears were stained with Diff-Quik solution (Dade Diagnostics of PR Inc, Aguada, Puerto Rico, USA). Two independent, blinded investigators counted the cells under a microscope. Approximately 400 cells were counted in each of four random locations. The inter-investigator variation was $<5 \%$, and the mean number of cells from both counts was used to estimate cell differentials.

\section{Administration of silver NPs}

Silver NPs were obtained from Nano Chemical Inc. (Daejeon, South Korea). Silver NPs were dissolved in PBS and administered by nebulizer (20 ppm, $40 \mathrm{mg} / \mathrm{kg}$ body weight/day) five times to each animal at 24-hour intervals for 5 days prior to each challenge day (days 19-24), beginning 1 hour before the first challenge.

\section{Determination of airway responsiveness}

Airway responsiveness was evaluated 48 hours after the final challenge, with the mice in an unrestrained conscious state. The mice were placed in a barometric plethysmographic chamber (All Medicus Co., Seoul, Korea), and baseline readings were taken and averaged for $3 \mathrm{~min}$. Increasing 
concentrations $(2.5-50 \mathrm{mg} / \mathrm{mL})$ of aerosolized methacholine were nebulized through an inlet into the main chamber for 3 min. Readings were taken and averaged for 2 min after each nebulization. Enhanced pause (Penh) was used as a measure of airway responsiveness to methacholine. Penh is a dimensionless value that represents a function of the proportion of maximal expiratory to maximal inspiratory box pressure signals and a function of the timing of expiration. It was calculated according to the manufacturer's protocol as: Penh $=($ expiratory time/relaxation time -1$) \times($ peak expiratory flow/peak inspiratory flow). The results are expressed as the increase in Penh following challenge with each concentration of methacholine, where the baseline Penh (after saline challenge) is defined as 1.

\section{Hematology and blood chemistry}

Blood samples were obtained within 24 hours after the administration of silver NPs by nebulizer (20 ppm, $40 \mathrm{mg} / \mathrm{kg}$ body weight/day) five times to each animal at 24 hour-intervals for 5 days. Mouse blood or serum was obtained from female, BALB/c inbred mice. Hematologic parameters were analyzed in EDTA blood samples with XE-2100 (Sysmex, Kobe, Japan), hematology analyzer.

Blood chemistry was determined in serum samples from the control and silver NPs inhaled group 24 hours after silver NPs administration (by nebulizer, $20 \mathrm{ppm}, 40 \mathrm{mg} / \mathrm{kg}$ body weight/day).

\section{Measurement of intracellular ROS}

ROS were measured using a previously described method..$^{20}$ BAL cells $\left(1 \times 10^{4}\right.$ cells $)$ were washed in PBS, incubated for $10 \mathrm{~min}$ at room temperature in PBS containing $3.3 \mu \mathrm{mol} / \mathrm{L}$ dichlorofluorescein diacetate (DCF-DA) (Molecular Probes, Eugene, OR, USA), transferred to polystyrene tubes with cell-strainer caps, and analyzed using a Cytomics FC 500 CXP flow cytometry system (Beckman Coulter Inc., Fullerton, CA, USA). We then measured the average percentage of cells that were either DCF-DA-unstained or -stained. Fluorescence images of intracellular ROS were acquired and analyzed using a fluorescence microscope (IX-71; Olympus Optical Co., Tokyo, Japan).

\section{Cytosolic or nuclear protein extraction for analysis of NF- $\kappa B$ p 65}

The lungs were removed and homogenized in 2 volume of buffer A (50 mmol/L Tris-HCl, pH 7.5, 1 mmol/L EDTA, 10\% glycerol, $0.5 \mathrm{mmol} / \mathrm{L}$ dithiothreitol [DTT], $5 \mathrm{mmol} / \mathrm{L} \mathrm{MgCl}_{2}$, and $1 \mathrm{mmol} / \mathrm{L}$ phenylmethanesulfonyl fluoride [PMSF]) containing protease inhibitor cocktail. The homogenates were centrifuged at $1,000 \times g$ for $15 \mathrm{~min}$ at $4^{\circ} \mathrm{C}$. The supernatants from the homogenates were incubated on ice for $10 \mathrm{~min}$ and centrifuged at $100,000 \times g$ for 1 hour at $4^{\circ} \mathrm{C}$, to obtain cytosolic proteins for the analysis of NF- $\mathrm{BB}$ p 65 levels. To prepare soluble nuclear proteins, the pellets from the homogenate were washed twice in buffer A, re-suspended in buffer B (1.3 $\mathrm{mmol} / \mathrm{L}$ sucrose, $1.0 \mathrm{mmol} / \mathrm{L} \mathrm{MgCl}_{2}$, and $10 \mathrm{mmol} / \mathrm{L}$ potassium phosphate buffer, $\mathrm{pH} 6.8$ ), and centrifuged at $1,000 \times g$ for $15 \mathrm{~min}$. The pellets were re-suspended in buffer $B$ with a final sucrose concentration of $2.2 \mathrm{~mol} / \mathrm{L}$ and centrifuged at $100,000 \times g$ for 1 hour. The resulting pellets were washed once with a solution containing $0.25 \mathrm{~mol} / \mathrm{L}$ sucrose, $0.5 \mathrm{mmol} / \mathrm{L} \mathrm{MgCl}_{2}$, and $20 \mathrm{mmol} / \mathrm{L}$ Tris- $\mathrm{HCl}, \mathrm{pH} 7.2$, and centrifuged at $1,000 \times g$ for $10 \mathrm{~min}$. These pellets were solubilized with a solution containing $50 \mathrm{mmol} / \mathrm{L}$ Tris- $\mathrm{HCl}$ (pH 7.2), $0.3 \mathrm{~mol} / \mathrm{L}$ sucrose, $150 \mathrm{mmol} / \mathrm{L} \mathrm{NaCl}, 2 \mathrm{mmol} / \mathrm{L}$ EDTA, 20\% glycerol, 2\% Triton X-100, 2 mmol/L PMSF, and protease inhibitor cocktail. The mixture was kept on ice for 1 hour with gentle stirring and then centrifuged at $12,000 \times g$ for $30 \mathrm{~min}$. The resulting supernatants were used as soluble nuclear proteins for the analysis of NF- $\kappa \mathrm{B}$ p 65. Protein levels were analyzed on Western blots, using an

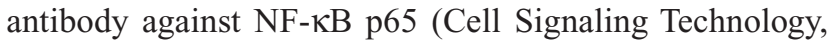
Beverly, MA, USA) as described above.

\section{RNA isolation and RT-PCR}

Total RNA from lung tissues was isolated using a rapid extraction method (TRI-Reagent; Montgomery Rd, OH, USA) as previously described. ${ }^{21} \mathrm{NA}$ was quantified by measuring absorption at $260 \mathrm{~nm}$ and was stored at $-80^{\circ} \mathrm{C}$ before use. Total RNA ( $4 \mu \mathrm{g}$ ) was reverse-transcribed to cDNA in a buffer containing $50 \mathrm{mM}$ Tris- $\mathrm{HCl}(\mathrm{pH} 9.0), 16 \mathrm{mM}\left(\mathrm{NH}_{4}\right)_{2} \mathrm{SO}_{4}$, $1.75 \mathrm{mM} \mathrm{MgCl}, 0.1 \mathrm{M}$ DTT; $1 \mu \mathrm{L}$ oligo(dT) $(500 \mu \mathrm{g} / \mathrm{mL})$, $10 \mathrm{mM}$ dNTP, 40 units RNase inhibitor, and $1 \mu \mathrm{L}$ SuperScript II RT (200 units/ $\mu \mathrm{L}$, Life Technologies, Grand Island, NY, USA), in a final vol of $20 \mu \mathrm{L}$. This mixture was incubated for $50 \mathrm{~min}$ at $42^{\circ} \mathrm{C}$ and was heated for $15 \mathrm{~min}$ at $70^{\circ} \mathrm{C}$ for enzyme inactivation. The first-strand cDNAs were used for PCR amplification of IL-4, IL-5, IL-13, or the housekeeping gene, GAPDH. PCR amplification was performed by mixing $3 \mu \mathrm{L}$ of the RT reaction mixture with $47 \mu \mathrm{L}$ of buffer containing $2.5 \mathrm{U}$ of Taq DNA polymerase (Promega, Madison, WI, USA) and 10 pmol of specific primer pairs for mouse cDNA of IL-4, IL-5, IL-13, or GAPDH, designed from published mouse gene sequences. The primers used were as follows: IL-4 (predicted length 400 bp) sense: 5'-CATCCTGCTCTTCTTTCTCGT-3', antisense: 5'-GTACTACGTGTAATCCATTTG-3'; IL-5 (predicted length 
201 bp) sense: 5'-GAGCACAGTGGTGAAAGAGAC-3', antisense: 5'-ATGACAGGTTTTGGAATAGCATTT-3'; IL-13 (predicted length $182 \mathrm{bp}$ ) sense: 5'-GCCAGCCCACAGTTCTA CAGC-3', antisense: 5'-GTGATGTTGCTCAGCTCCTCA-3' and GAPDH (predicted length 609 bp) sense: $5^{\prime}$-GCCA TCAACGACCCCTTCATTGAC-3', antisense: 5'-ACG GAAGGCCATGCCAGTGAGCTT-3'. PCR reactions were performed in a thermocycler (GeneAmp ${ }^{\circledR}$ PCR System 2400, Foster City, CA, USA) using the following reaction conditions; after an initial incubation for $5 \mathrm{~min}$ at $95^{\circ} \mathrm{C}$, samples were subjected to 27 cycles (GAPDH) or 35 cycles (IL-4, IL-5, IL-13) of $5 \mathrm{~min}$ at $94^{\circ} \mathrm{C}, 30 \mathrm{sec}$ at $60^{\circ} \mathrm{C}(\mathrm{GAPDH}), 60^{\circ} \mathrm{C}$ (IL-4), $58^{\circ} \mathrm{C}$ (IL-5), $60^{\circ} \mathrm{C}$ (IL-13) and $1 \mathrm{~min}$ at $72^{\circ} \mathrm{C}$. A final extension step at $72^{\circ} \mathrm{C}$ for $10 \mathrm{~min}$ was performed. The RT-PCR products were electrophoretically fractioned on $2 \%$ agarose gels stained with ethidium bromide. DNA bands were visualized after exposure to UV light.

\section{Western blot analysis}

Lung tissues were homogenized in the presence of protease inhibitors, and protein concentrations were determined using the Bradford assay (Bio-Rad Laboratories Inc., Hercules, CA, USA). Samples were loaded onto a gel and subjected to SDS-PAGE at $120 \mathrm{~V}$ for $90 \mathrm{~min}$. The separated proteins were transferred to nitrocellulose membranes (GE Healthcare Bio-Sciences, Piscataway, NJ, USA) via the wet transfer method (250 mA, $90 \mathrm{~min}$ ). Nonspecific sites on the membranes were blocked by incubation for 1 hour in $5 \%$ non-fat dry milk in Tris-buffered saline containing Tween 20 (TBST; $25 \mathrm{mmol} / \mathrm{L}$ Tris, pH7.5, $150 \mathrm{mmol} / \mathrm{L} \mathrm{NaCl}, 0.1 \%$ Tween 20), and the blots were then incubated overnight at $4{ }^{\circ} \mathrm{C}$ with an anti-IL-4 antibody (Serotec Ltd, Oxford, UK), anti-IL-5 antibody (Santa Cruz Biotechnology, Santa Cruz, CA, USA), or anti-IL-13 antibody (R\&D Systems, Inc., Minneapolis, MN, USA). Anti-rat or anti-mouse horseradish peroxidase-conjugated $\mathrm{IgG}$ was used to detect antibody binding. The membranes were stripped and re-probed with an anti-actin antibody (Sigma-Aldrich) to verify equal loading of proteins in each lane. Specific antibody binding was visualized by exposure of the membranes to photographic film, after treatment with enhanced chemiluminescence system reagents (GE Healthcare Bio-Sciences, Piscataway, NJ, USA).

\section{Histological image analysis}

For histological analysis, the mice were sacrificed 72 hours after the final challenge, and the lungs and trachea were filled with fixative $(0.8 \%$ formalin, $4 \%$ acetic acid $)$. The trachea was ligated, and the lungs and trachea were dissected out.
The lung tissues were fixed with 10\% (volume/volume) neutral-buffered formalin. Specimens were dehydrated and embedded in paraffin, and 4- $\mu \mathrm{m}$-thick sections were cut using a Leica model 2165 rotary microtome (Leica Microsystems Nussloch GmbH, Nussloch, Germany). The sections were placed on slides, deparaffinized, and stained sequentially with hematoxylin 2 and eosin-Y (Richard-Allan Scientific, Kalamazoo, MI, USA). All stained slides were evaluated via light microscopy under identical conditions with respect to magnification $(20 \times)$, gain, camera position, and background illumination. ${ }^{22}$ The degrees of peribronchial and perivascular inflammation were scored by three independent, blinded investigators using a subjective scale of $0-3$ ( 0 , no detectable inflammation; 1 , occasional cuffing with inflammatory cells; 2 , most bronchi or vessels surrounded by a thin layer of between one and five inflammatory cells; 3 , most bronchi or vessels surrounded by a thick layer of more than five inflammatory cells), as described elsewhere. ${ }^{23}$ Total lung inflammation was defined as the average of the peribronchial and perivascular inflammation scores.

\section{Densitometric analysis and statistics}

All immunoreactive signals were scanned and densitometric analyses were performed using a Gel-Pro Analyzer (Media Cybernetics, Silver Spring, MD, USA). Data are expressed as the mean \pm SEM. Statistical comparisons were made using one-way analysis of variance (ANOVA) followed by Scheffe's test. Significant differences between two groups were determined using an unpaired Student's $t$-test. Statistical significance was set at $P<0.05$.

\section{Results \\ Morphological characterization of silver NPs}

TEM was used to study the morphology and particle size of the silver NPs (Figure 1). The particles have a spherical shape. Mean particle size is $6.0 \pm 0.29 \mathrm{~nm}$.
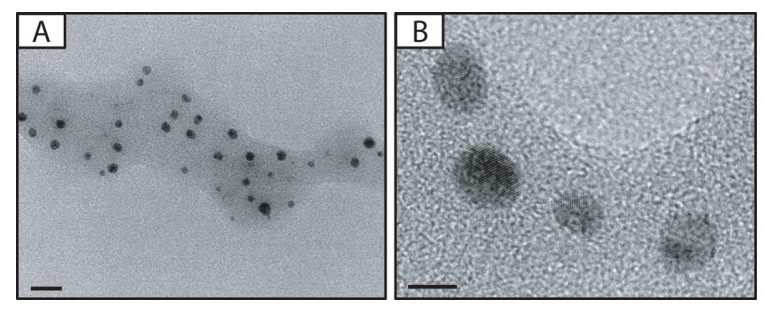

Figure I A) Photomicrographs of silver nanoparticles (NPs). B) Transmission electron microscopic image of bulk of silver NPs. Bars in A) and B) indicate $20 \mathrm{~nm}$ and $5 \mathrm{~nm}$, respectively. 


\section{Effect of silver NPs on hematologic and serum chemistry profiles}

To determine systemic effects of silver NPs, we introduced hematologic and serum chemistry profiles. For example, C-reactive protein, an acute-phase protein, is used as a biomarker of inflammation and lactate dehydrogenase is used as a marker of cytotoxicity. No significant changes in any of the hematological or serum chemistry parameters measured were observed in the inhalation exposure to silver NPs compared with the control (Tables 1 and 2). Only minor differences on serum chemistry levels were observed (Table 2).

\section{Effect of silver NPs on intracellular ROS levels in BAL cells from OVA-sensitized and OVA-challenged mice}

Intracellular ROS generation was examined under a fluorescence microscope, and ROS levels were quantified via FACScan analysis. ROS generation in BAL cells was significantly higher at 72 hours after OVA inhalation compared with ROS generation after saline inhalation $(31.3 \pm 1.1$ vs $24.5 \pm 1.4 \%$, respectively). This increase in ROS generation was substantially attenuated by the administration of silver NPs $(28.0 \pm 1.2 \%)$ (Figure 2 ).

\section{Effect of silver NPs on NF- $\kappa B$ p 65 protein levels in lung tissues from OVA-sensitized and OVA-challenged mice} Western blot analysis showed a significant increase in $\mathrm{NF}-\kappa \mathrm{B}$ p65 in the nuclear protein extracts from lung tissues at 72 hours after OVA inhalation, compared with the level in control mice (Figure 3). This increase in NF- $\kappa \mathrm{B}$ p65 after OVA inhalation was decreased significantly with the administration of silver NPs. In contrast, NF- $\kappa$ B p65 in the cytosolic protein fractions from lung tissues was decreased after OVA inhalation, compared with the level in control mice, and this decrease in cytosolic NF- $\kappa$ B p65 was also attenuated by the administration of silver NPs.

Table I Effect of inhalation exposure to silver NPs on hematologic profiles

\begin{tabular}{llll}
\hline & SAL & Ag & $\boldsymbol{P}$ \\
\hline WBC & $3,530 \pm 460.32$ & $3,550 \pm 625.539$ & 0.98 \\
RBC & $8.60 \pm 0.32$ & $8.96 \pm 0.47$ & 0.55 \\
Hb & $14.33 \pm 0.16$ & $13.66 \pm 0.23$ & 0.08 \\
Hct & $41.96 \pm 1.39$ & $42.83 \pm 0.81$ & 0.62 \\
PLT $\left(\times 10^{6}\right)$ & $4.13 \pm 2.33$ & $3.59 \pm 5.34$ & 0.42 \\
\hline
\end{tabular}

Abbreviations: SAL, saline inhaled mice; Ag, silver NPs inhaled mice; WBC, white blood cell; RBC, red blood cell; $\mathrm{Hb}$, hemoglobin; Hct, hematocrit; PLT, platelet.
Table 2 Effect of inhalation exposure to silver NPs on serum chemistry profiles

\begin{tabular}{llll}
\hline & SAL & Ag & $\boldsymbol{P}$ \\
\hline TP & $4.4 \pm 0.72$ & $4.44 \pm 0.06$ & 0.65 \\
ALB & $1.6 \pm 0.03$ & $1.62 \pm 0.01$ & 0.51 \\
AST & $111.14 \pm 14.18$ & $153.16 \pm 18.15$ & 0.91 \\
ALT & $30.85 \pm 1.1$ & $34.33 \pm 1.2$ & 0.56 \\
ALP & $159.71 \pm 5.56$ & $139.14 \pm 4.76$ & 0.16 \\
LDH & $742.66 \pm 82.39$ & $841 \pm 145.51$ & 0.60 \\
CRP & $0.1 \pm 0.00$ & $0.1 \pm 0.00$ & NA \\
BUN & $18.18 \pm 1.7$ & $23.58 \pm 2.44$ & 0.14 \\
CREA & $0.11 \pm 0.01$ & $0.13 \pm 0.01$ & 0.2 \\
\hline
\end{tabular}

Abbreviations: SAL, saline inhaled mice; Ag, silver NPs inhaled mice; TP, total protein; ALB, albumin; AST, asparte aminotransferase; ALT, alanine aminotransferase; ALP, alkaline phosphatase; LDH, lactate dehydrogenase; CRP, C-reactive protein; BUN, blood urea nitrogen; CREA, creatinine.

Effect of silver NPs on IL-4, IL-5, and IL- 13 expression in lung tissues of OVA-sensitized and OVA-challenged mice RT-PCR revealed that IL-4, IL-5, and IL-13 mRNA levels were increased substantially in lung tissues at 72 hours after OVA inhalation, compared with the levels after saline inhalation (Figure 4A). These increases were inhibited by the administration of silver NPs. Consistent with these results, Western blot analysis also demonstrated that cytokine levels in lung tissues were increased significantly at 72 hours after OVA inhalation, compared with the levels in control mice (Figures 4B and 4C) and that these increases were inhibited by the administration of silver NPs.

\section{Effect of silver NPs on cellular changes in BAL fluids and lung inflammation of OVA-sensitized and OVA-challenged mice} The numbers of total cells, eosinophils, lymphocytes, and neutrophils in BAL fluids were increased significantly at 72 hours after OVA inhalation, compared with the cell counts after saline inhalation (Figure 5F), and the administration of silver NPs blocked these increases in cell counts after OVA inhalation. Similarly, the scores for total lung inflammation were significantly increased at 72 hours after OVA inhalation, compared with the scores after saline inhalation (Figure 5E). The total lung inflammation scores after OVA inhalation were significantly lower with the administration of silver NPs.

\section{Effect of silver NPs on airway} hyperresponsiveness

Airway responsiveness was assessed based on the increase in Penh in response to increasing doses of methacholine. 

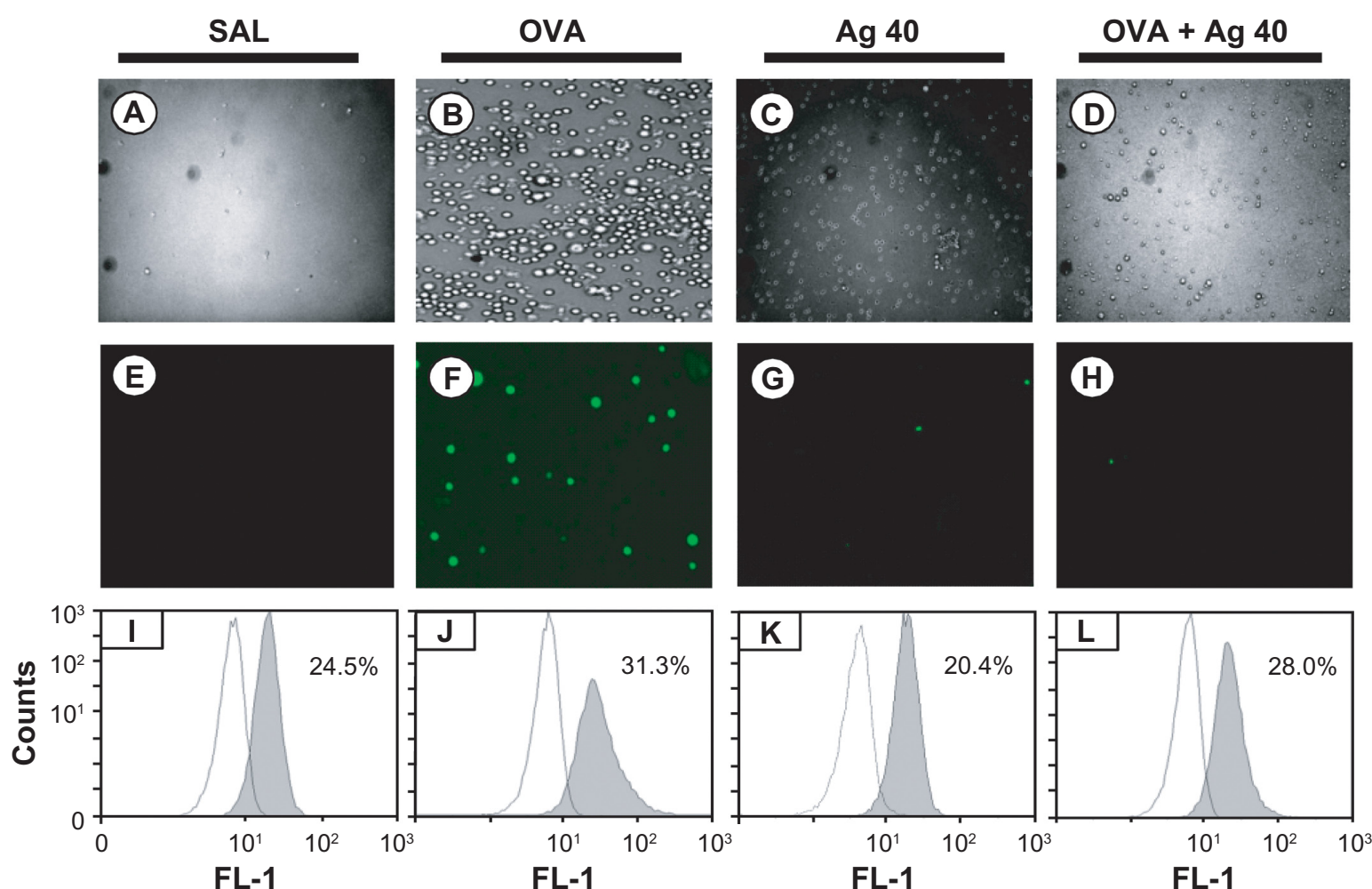

Figure 2 Effect of silver nanoparticles (NPs) on intracellular reactive oxygen species (ROS) levels in bronchoalveolar lavage (BAL) cells from ovalbumin (OVA)-sensitized and OVA-challenged mice. Sampling was performed 72 hours after the final challenge. A-D) Representative microphotographs show the dichlorofluorescein (DCF) fluorescence intensity of cells from saline-inhaled mice administered saline A), OVA-inhaled mice administered saline B), saline-inhaled mice administered 40 mg/kg of silver NPs (C), and OVA-inhaled mice administered $40 \mathrm{mg} / \mathrm{kg}$ of silver NPs D). E-H) Corresponding transmission light microphotographs are shown. I-L) A representative frequency histogram of the fluorescence intensity of cells from saline-inhaled mice administered saline (SAL), OVA-inhaled mice administered saline (OVA), saline-inhaled mice administered $40 \mathrm{mg} / \mathrm{kg}$ of silver NPs (Ag 40), and OVA-inhaled mice administered $40 \mathrm{mg} / \mathrm{kg}$ of silver NPs (OVA + Ag 40).

In OVA-sensitized and OVA-challenged mice, the Penh dose-response curve was shifted to the left compared with the control curve (Figure 6). In addition, Penh produced by the administration of $50 \mathrm{mg} / \mathrm{mL}$ methacholine was significantly greater in OVA-inhaled mice than in control mice. OVAsensitized and OVA-challenged mice treated with silver NPs showed a substantial reduction in Penh at $50 \mathrm{mg} / \mathrm{mL}$ methacholine compared with untreated mice after OVA inhalation. These results indicate that silver NP treatment reduces OVA-induced airway hyperresponsiveness.

\section{Discussion}

Bronchial asthma is a chronic inflammatory disease of the airways characterized by airway eosinophilia, goblet cell hyperplasia with mucus hypersecretion, and hyperresponsiveness to inhaled allergens and nonspecific stimuli. ${ }^{24,25}$ There is increasing evidence that inflammation, which is characteristic of asthma, results in increased oxidative stress in the airways. ${ }^{26}$ Eosinophils, alveolar macrophages, and neutrophils from asthmatic patients produce more ROS than do those from normal subjects. ${ }^{27-30}$ ROS are involved in airway smooth muscle contraction, impairment of $\beta$-adrenergic receptors, decreased number and function of epithelial cilia, increased mucus production, altered release of inflammatory mediators, influx of inflammatory cells, and increased vascular permeability. ${ }^{31}$

The overproduction of ROS or depression of protective mechanisms also results in bronchial hyperreactivity, which is characteristic of asthma. ${ }^{32-34}$ ROS directly cause contraction of airway smooth muscle preparations, and this effect is enhanced when the epithelium is injured or removed. ${ }^{32}$ Studies in animal models have indicated that ROS contribute to airway hyperresponsiveness by increasing vagal tone due to damage of oxidant-sensitive $\beta$-adrenergic receptors as well as decreased mucociliary clearance..$^{35,36}$

ROS appear to directly stimulate the release of histamine from mast cells and mucus secretion from airway epithelial cells. ${ }^{37}$ Increased ROS release may directly result in oxidative damage to epithelial cells and cell shedding. ${ }^{29}$ Previous studies have suggested that ROS may lead to endothelial barrier dysfunction, with subsequent increased permeability to fluid, macromolecules, and inflammatory cells. ${ }^{31}$

The present study using an OVA-induced model of allergic airway disease demonstrated that ROS production 
A
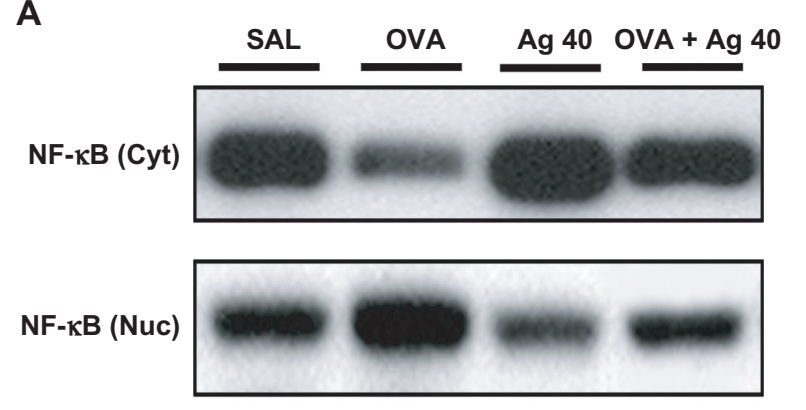

B

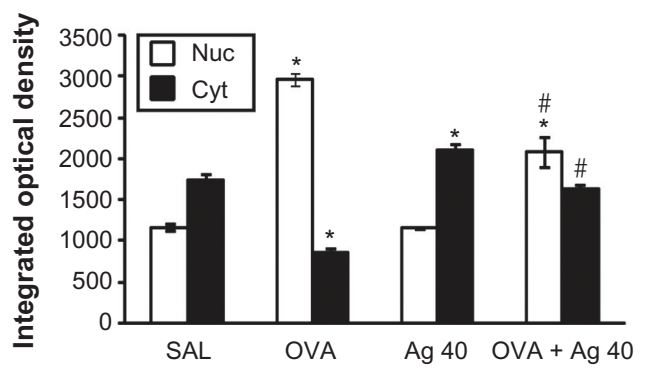

Figure 3 Effect of silver nanoparticles (NPs) on the protein expression of NF- $\mathrm{KB}$ p65 in lung tissues collected from ovalbumin (OVA)-sensitized and OVA-challenged mice. NF- $K B$ p 65 were measured 72 hours after the final challenge in saline-inhaled mice administered saline (SAL), OVA-inhaled mice administered saline (OVA), salineinhaled mice administered $40 \mathrm{mg} / \mathrm{kg}$ of silver NPs (Ag 40), and OVA-inhaled mice administered $40 \mathrm{mg} / \mathrm{kg}$ of silver NPs (OVA + Ag 40). A) Western blot analyses of NF- $\mathrm{KB}$ p65 in nuclear (Nuc) and cytosolic (Cyt) protein extracts from lung tissues. B) NF-KB p65 protein levels in (A) were quantified using a Gel-Pro Analyzer (Media Cybernetics, Silver Spring, MD, USA) and plotted as the integrated optical density, using Microsoft Excel. Bars indicate the mean \pm SEM and are representative of eight independent experiments using different preparations of nuclear and cytosolic extracts. ${ }^{*} P<0.05$ versus $S A L ;{ }^{*} P<0.05$ versus OVA.

was increased in cells from BAL fluids and that the administration of silver NPs significantly attenuated ROS generation, Th2 cytokine expression, bronchial inflammation, and airway hyperresponsiveness in OVA-challenged mice.

We also noted that the increased levels of nuclear NF- $\mathrm{KB}$ induced by OVA inhalation were decreased with the administration of silver NPs. NF- $\mathrm{\kappa B}$ is a multiprotein complex that is known to activate a large number of genes involved in early cellular defense reactions in higher organisms. In non-stimulated cells, inactive NF- $\mathrm{KB}$ is found in the cytosol. ${ }^{38}$ $\mathrm{NF}-\kappa \mathrm{B}$ plays an important role in immune and inflammatory responses and is present in most cell types. ${ }^{39-43}$ The role of ROS in the activation of NF- $\mathrm{KB}$ signal transduction was initially observed in cells treated with $\mathrm{H}_{2} \mathrm{O}_{2} \cdot{ }^{44} \mathrm{~A}$ recent study reported that the development of an oxidant/antioxidant imbalance in asthma leads to the activation of the redoxsensitive transcription factor NF- $\kappa B .{ }^{45}$ ROS have been directly implicated as second messengers in the activation of $\mathrm{NF}-\kappa \mathrm{B}$, based upon the ability of oxidants to activate NF- $\mathrm{BB}$ via oxidation of its cysteine-SH group or via ubiquitination and proteolysis of IKB. ${ }^{46-48}$
A

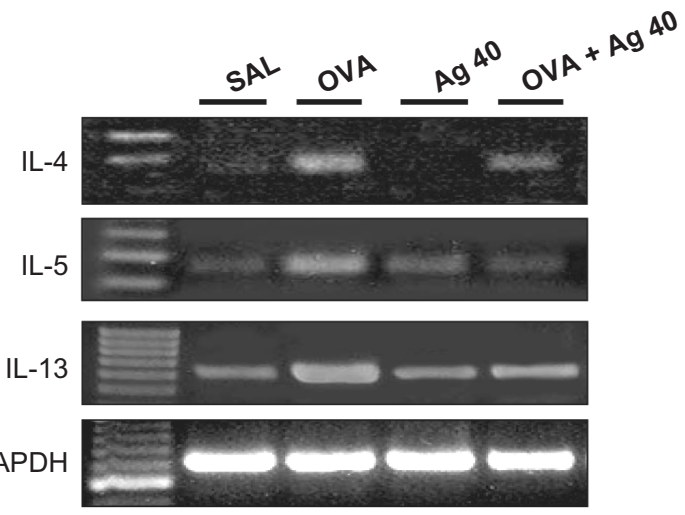

B
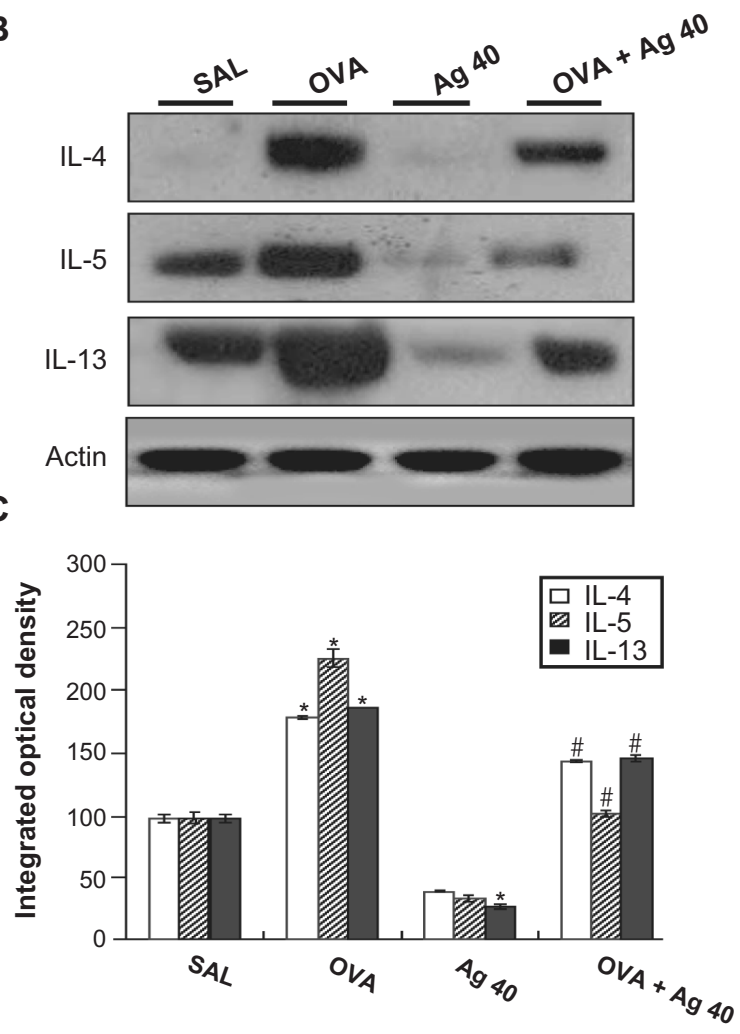

Figure 4 Effect of silver nanoparticles (NPs) on IL-4, IL-5, and IL- I3 expression in lung tissues collected from ovalbumin (OVA)-sensitized and OVA-challenged mice. Sampling was performed 72 hours after the final challenge in saline-inhaled mice administered saline (SAL), OVA-inhaled mice administered saline (OVA), saline-inhaled mice administered $40 \mathrm{mg} / \mathrm{kg}$ of silver NPs (Ag 40), and OVA-inhaled mice administered $40 \mathrm{mg} / \mathrm{kg}$ of silver NPs (OVA + Ag 40). A) RT-PCR results. B) Western blot analyses of IL-4, IL-5, and IL-I3 in lung tissues. C) Quantification of the IL-4, IL-5, and IL-13 protein levels in B) using Gel-Pro Analyzer (Media Cybernetics, Silver Spring, MD, USA). The relative protein content was calculated as the ratio of the integrated optical density of each protein to that of actin. The ratio is arbitrarily presented as $100 \%$. Bars indicate the mean \pm SEM and are representative of eight independent experiments using different preparations of lung tissues. $* P<0.05$ versus $S A L ; ~ \# P<0.05$ versus OVA.

NF- $\kappa B$ activation induces the transcription of a variety of inflammatory genes that are abnormally expressed in asthma, including cytokines (eg, IL-4, IL-5, IL-9, IL-15, and tumor necrosis factor $[\mathrm{TNF}]-\alpha$ ), chemokines (eg, regulated upon activation, normal T-cell expressed and secreted; eotaxin; and monocyte chemotactic protein-3), and adhesion molecules 

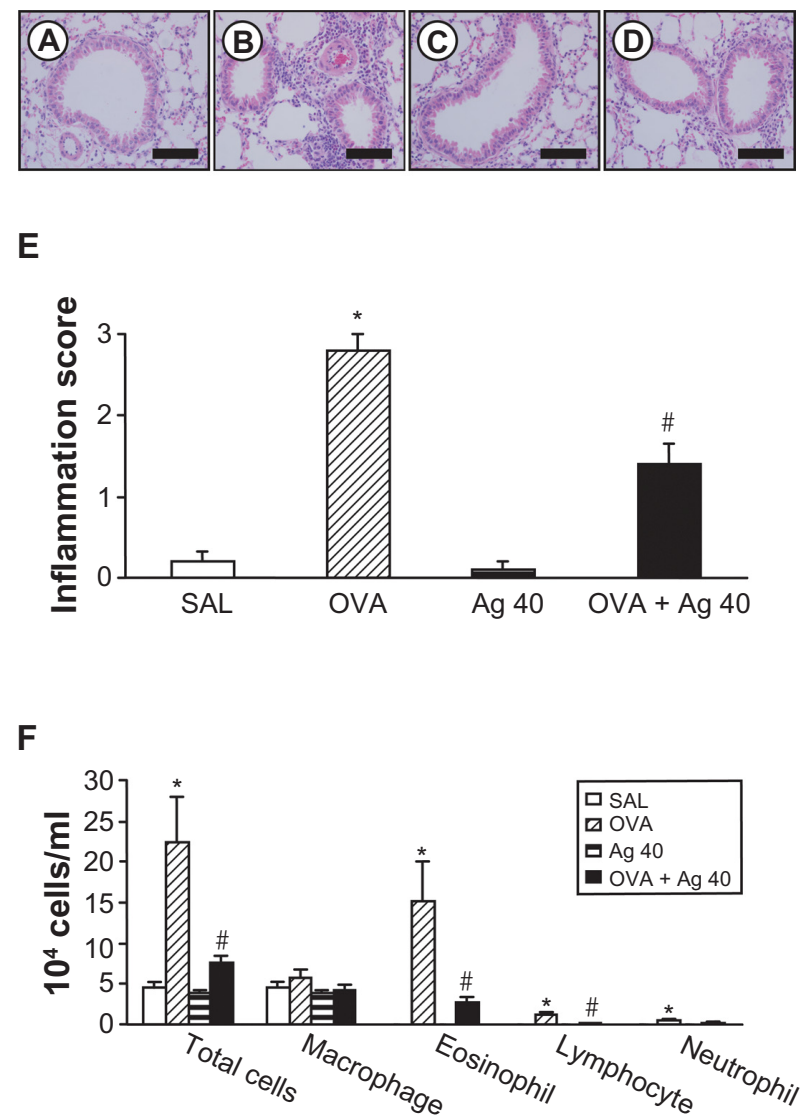

Figure 5 Effect of silver nanoparticles (NPs) on bronchial inflammation in ovalbumin (OVA)-sensitized and OVA-challenged mice. Sampling was performed 72 hours after the final challenge in saline-inhaled mice administered saline (SAL), OVA-inhaled mice administered saline (OVA), saline-inhaled mice administered $40 \mathrm{mg} / \mathrm{kg}$ of silver NPs (Ag 40), and OVA-inhaled mice administered $40 \mathrm{mg} / \mathrm{kg}$ of silver NPs (OVA + Ag 40). A-D) Representative H\&E-stained sections of the lungs. Bars indicate scale of $50 \mu \mathrm{m}$. E) Total lung inflammation scores. F) The numbers of total and differential cellular components of bronchoalveolar lavage (BAL) fluids. Bars indicate the mean \pm SEM for eight mice per group in four to six independent experiments. $* P<0.05$ versus $S A L ; ~ * P<0.05$ versus OVA.

(eg, intercellular adhesion molecule-1 and vascular cell adhesion molecule-1). ${ }^{21,43,49,50}$ In a recent study, the antioxidant L-2-oxothiazolidine-4-carboxylic acid (OTC) was shown to inhibit airway inflammation in a murine model of asthma. ${ }^{51}$ In that study, OTC administration significantly reduced NF- $\kappa$ B translocation into the nucleus and the expression of adhesion molecules, chemokines, and cytokines. These results show that OTC inhibits NF- $\kappa \mathrm{B}$ activity by preventing the ROS-induced translocation of this transcription factor into nucleus. Antioxidants have also been reported to inhibit NF- $\kappa \mathrm{B}$ activation by preventing $\mathrm{I} \kappa \mathrm{B}$ degradation in response to various stimuli. ${ }^{52-56}$ Taken together, these findings indicate that the activation of NF- $\mathrm{KB}$ by ROS is a critical signaling mechanism for evoking inflammatory responses.

Our results suggest that silver NPs attenuate airway inflammation and hyperresponsiveness through the modulation of ROS generation, which subsequently

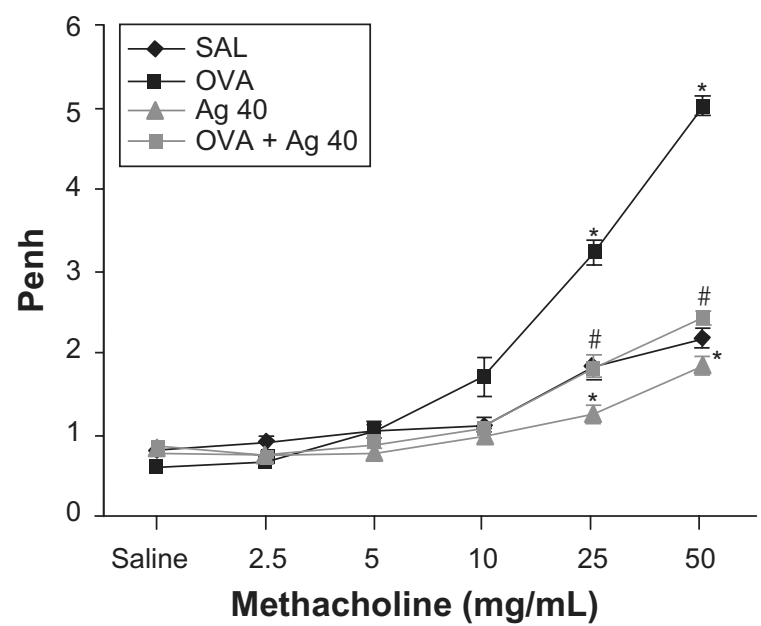

Figure 6 Effect of silver nanoparticles (NPs) on airway responsiveness to inhaled methacholine in ovalbumin (OVA)-sensitized and OVA-challenged mice. Airway hyperresponsiveness was measured at $48 \mathrm{~h}$ after the final challenge in saline-inhaled mice administered saline (SAL), OVA-inhaled mice administered saline (OVA), salineinhaled mice administered $40 \mathrm{mg} / \mathrm{kg}$ of silver NPs (Ag 40), and OVA-inhaled mice administered $40 \mathrm{mg} / \mathrm{kg}$ of silver NPs (OVA $+\mathrm{Ag} 40$ ). Penh values were obtained in response to increasing doses $(2.5-50 \mathrm{mg} / \mathrm{mL})$ of methacholine. Bars indicate the mean \pm SEM for eight mice per group in four to six independent experiments. $* P<0.05$ versus $S A L ;{ }^{\#} P 0.05$ versus OVA.

attenuates the expression of inflammatory cytokines and $\mathrm{NF}-\kappa \mathrm{B}$ activation in mice with allergic airway disease. Thus, silver NPs appear to act as antioxidative and/or antiinflammatory agents, based on this study. Nanocrystalline silver (NPI 32101) has been demonstrated to have antiinflammatory properties through both its topical and oral use, as shown in previous experimental studies. ${ }^{57-60}$ In these studies, nanocrystalline silver was shown to significantly suppress the expression of IL- $\beta$, IL-12, metalloproteinase-9, and TNF- $\alpha .{ }^{57,59}$ When nanocrystalline silver was introduced intravesically in a rat cystitis model, it decreased the number of mast cells and the extent of mast cell degranulation. ${ }^{60}$ However, there are also experiments showing that silver NPs induced inflammation. ${ }^{61,62}$ Proinflammatory cytokines, such as TNF- $\alpha$, are rapidly secreted upon stimulation with various nanoparticles in macrophage RAW 264.7 cells. ${ }^{63,64}$ It has been proposed that nanosilver modulates cytokine production in a concentration-dependent manner. ${ }^{62}$ These conflict between various studies regarding the properties of nanoparticles, including silver NPs, illustrate that the role of the immune system is still being clarified. Among various inorganic nanoparticles, gold nanoparticles, platinum nanoparticles, and nano red elemental selenium have been reported to show antioxidative effects. ${ }^{9-11,21-23}$ However, the precise mechanism of quenching induced by platinum nanoparticles remains unclear, and although selenium is one of the essential metals in the body, contamination with sodium serenite makes the use of nanoselenium difficult in 
biological applications. In the present study, we were unable to identify the exact mechanism underlying the effects of silver NP treatment, but the results of our $2^{\prime}, 7^{\prime}$-DCF-DA and FACS analysis support an antioxidative effect in this murine model of asthma. To our knowledge, this is the first report demonstrating the antioxidative effects of silver NPs. However, studies indicating that silver NPs may generate free radicals have also been published. ${ }^{65,66}$

Despite the potential usefulness of silver NPs as antioxidative or anti-inflammatory agents, as indicated by this study, unresolved issues remain. First, the pharmacokinetics of silver NPs are not fully understood. Second, it is unclear where silver NPs scavenge ROS in the body of the mouse. That is, we did not determine the exact location of silver NP activity at the cellular level. Third, it may be important to control the concentration of silver NPs in order to scavenge only excess ROS and maintain the optimal ROS level. Fourth, controversy remains regarding the inflammatory/anti-inflammatory effects of silver NPs. Recent studies have reported that silver NPs exerted antiinflammatory effects through the modulation of cytokine production, particularly Th1 cytokines, and mast cell activation. $^{57,60,62}$ Other studies have suggested that silver NPs have inflammatory effects. ${ }^{61,63,67}$ These conflicting results may be attributable to several confounding factors such as particle size, surface charge, delivery method, route of administration, duration of administration, dose, and/or disease conditions (intra/extracellular milieu), which may alter the bioactive characteristics of nanoparticles in particular cells or tissue types.

In summary, although further studies are needed, our study suggests that oxidative stress is an important determinant of allergic airway disease and that silver NPs attenuated oxidative stress in the murine asthma model. Also, by administration of silver NPs, Th2 inflammation, which is one of the main asthma-inducing immune factors, was significantly decreased. We suggest that silver NPs may be useful as a therapeutic strategy through their properties as antioxidant and anti-inflammatory agents.

\section{Acknowledgments}

The English in this document has been checked by at least two professional editors, both native speakers of English.

We give special thanks to Prof Minho Shong, Chungnam National University, who supported much of the experimental work. We also thank Prof Yong Chul Lee, Chonbuk National University, for insightful recommendations and advice.

\section{Grant support}

This research was supported by Chungnam National University Hospital Research Fund, 2006.

\section{Disclosure}

No conflict of interest has been declared.

\section{References}

1. Tsuji JS, Maynard AD, Howard PC, et al. Research strategies for safety evaluation of nanomaterials, part IV: risk assessment of nanoparticles. Toxicol Sci. 2006;89:42-50.

2. Heger M. Safety of new bacteria-killing coating questioned. Scienceline. 2008 Apr 21. http://www.livescience.com/technology/080421-silvernano.html

3. El-Sayed MA. Small is different: shape-, size-, and compositiondependent properties of some colloidal semiconductor nanocrystals. Acc Chem Res. 2004;37:326-333.

4. Ho CM, Yu WY, Che CM. Ruthenium nanoparticles supported on hydroxyapatite as an efficient and recyclable catalyst for cisdihydroxylation and oxidative cleavage of alkenes. Angew Chem Int Ed. 2004;43:3303-3307.

5. Lang H, May RA, Iversen BL, Chandler BD. Dendrimer-encapsulated nanoparticle precursors to supported platinum catalysts. $J$ Am Chem Soc. 2003;125:14832-14836.

6. Lewis LN. Chemical catalysis by colloids and clusters. Chem Rev. 1993; 93:2693-2730.

7. Nicewarner-Pena SR, Freeman RG, Reiss BD, et al. Submicrometer metallic barcodes. Science. 2001;294:137-141.

8. Elghanian R, Storhoff JJ, Mucic RC, Letsinger RL, Mirkin CA. Selective colorimetric detection of polynucleotides based on the distance-dependent optical properties of gold nanoparticles. Science. 1997;277:1078-1081.

9. Kajita M, Hikosaka K, Iitsuka M, Kanayama A, Toshima N, Miyamoto Y. Platinum nanoparticle is a useful scavenger of superoxide anion and hydrogen peroxide. Free Radic Res. 2007;41:615-626.

10. Huang B, Zhang J, Hou J, Chen C. Free radical scavenging efficiency of nano-Se in vitro. Free Radic Biol Med. 2003;35:805-813.

11. Kim J, Takahashi M, Shimizu T, et al. Effects of a potent antioxidant, platinum nanoparticle, on the lifespan of Caenorhabditis elegans. 2008; 129:322-331.

12. Modak SM, Fox CL Jr. Binding of silver sulfadiazine to the cellular components of Pseudomonas aeruginosa. Biochem Pharmacol. 1973; 22:2391-2404.

13. Hanif J, Tasca RA, Frosh A, Ghufoor K, Stirling R. Silver nitrate: histological effects of cautery on epithelial surfaces with varying contact times. Clin Otolaryngol Allied Sci. 2003;28:368-370.

14. Antonangelo L, Vargas FS, Teixeira LR, et al. Pleurodesis induced by talc or silver nitrate evaluation of collagen and elastic fibers in pleural remodeling. Lung. 2006;184:105-111.

15. Sun RW, Chen R, Chung NP, Ho CM, Lin CL, Che CM. Silver nanoparticles fabricated in herpes buffer exhibit cytoprotective activities toward HIV-1 infected cells. Chem Commun. 2005;40:5059-5061.

16. Tian J, Wong K, Ho CM, et al. Topical delivery of silver nanoparticles promotes wound healing. Chem Med Chem. 2007;2:129-136.

17. Wright JB, Lam K, Buret AG, Olson ME, Burrell RE. Early healing events in a porcine model of contaminated wounds: effects of nanocrystalline silver on matrix metalloproteinases, cell apoptosis, and healing. Wound Rep Reg. 2002;10:141-151.

18. Oberdorster G, Oberdorster E, Oberdorster J. Nanotoxicology: an emergin discipline evolving from studies of ultrafine particles. Environ Health Perspect. 2005;113:823-839.

19. Maynard AD, Kuempel ED. Airborne nanostructured particles and occupational health. J Nanoparticle Res. 2005;7:587-614. 
20. Lee KS, Kim SR, Park SJ, et al. Peroxisome proliferator activated receptor-gamma modulates reactive oxygen species generation and activation of nuclear factor-kappaB and hypoxia-inducible factor lalpha in allergic airway disease of mice. J Allergy Clin Immunol. 2006;118:120-127.

21. Chomczynski P, Sacchi N. Single-step method of RNA isolation by acid guanidium thiocyanate-phenol-chloroform extraction. Anal Biochem. 1987;162:156-159.

22. Cho JY, Miller M, Baek KJ, et al. Inhibition of airway remodeling in IL-5-deficient mice. J Clin Invest. 2004;113:551-560.

23. Tournoy KG, Kips JC, Schou C, Pauwels RA. Airway eosinophilia is not a requirement for allergen-induced airway hyperresponsiveness. Clin Exp Allergy. 2000;30:79-85.

24. Kay AB. Asthma and inflammation. J Allergy Clin Immunol. 1991; 87:893-910.

25. Bousquet J, Jeffery PK, Busse WW, Johnson M, Vignola AM. Asthma: from bronchoconstriction to airways inflammation and remodeling. Am J Respir Crit Care Med. 2000;161:1720-1745.

26. Dworski R. Oxidant stress in asthma. Thorax. 2000;55:S51-S53.

27. Calhoun WJ, Reed HE, Moest DR, Stevens CA. Enhanced superoxide production by alveolar macrophages and airspace cells, airway inflammation, and alveolar macrophage density changes follow segmental antigen bronchoprovocation in allergic subjects. Am Rev Respir Dis. 1992;145:317-325.

28. Calhoun WJ, Bush RK. Enhanced reactive oxygen species metabolism of airspace cells and airway inflammation following antigen challenge in human asthma. J Allergy Clin Immunol. 1990;86:306-313.

29. Schauer U, Leinhaas C, Jäger R, Rieger CH. Enhanced superoxide generation by eosinophils from asthmatic children. Int Arch Allergy Appl Immunol. 1991;96:317-321.

30. Teramoto S, Shu CY, Ouchi Y, Fukuchi Y. Increased spontaneous production and generation of superoxide anion by blood neutrophils in patients with asthma. J Asthma. 1996;33:149-155.

31. Henricks PA, Nijkamp FP. Reactive oxygen species as mediators in asthma. Pulm Pharmacol Ther. 2001;14:409-420.

32. Hulsmann AR, Raatgeep HR, den Hollander JC, et al. Oxidative epithelial damage produces hyperresponsiveness of human peripheral airways. Am J Respir Crit Care Med. 1994;149:519-525.

33. Cortijo J, Marti-Cabrera M, de la Asuncion JG, et al. Contraction of human airways by oxidative stress protection by $\mathrm{N}$-acetylcysteine. Free Radic Biol Med. 1999;27:392-400.

34. Sadeghi-Hashjin G, Folkerts G, Henricks PA, et al. Peroxynitrite induces airway hyperresponsiveness in guinea pigs in vitro and in vivo. Am J Respir Crit Care Med. 1996;153:1697-1701.

35. Adam L, Bouvier M, Jones TL. Nitric oxide modulates beta(2)adrenergic receptor palmitoylation and signaling. J Biol Chem. 1999;274:26337-26343.

36. Owen S, Pearson D, Suarez-Mendez V, O’Driscoll R, Woodcock A. Evidence of free-radical activity in asthma. N Engl J Med. 1991;325: 586-587.

37. Krishna MT, Madden J, Teran LM, et al. Effects of 0.2 ppm ozone on biomarkers of inflammation in bronchoalveolar lavage fluid and bronchial mucosa of healthy subjects. Eur Respir J. 1998;11:1294-1300.

38. Baldwin AS Jr. The NF-kappa B and I kappa B proteins: new discoveries and insights. Annu Rev Immunol. 1996;14:649-683.

39. Siebenlist U, Franzoso G, Brown K. Structure, regulation and function of NF-kappa B. Annu Rev Cell Biol. 1994;10:405-455.

40. Baeuerle PA, Baltimore D. NF-kappa B: ten years after. Cell. 1996;87: 13-20.

41. Gilmore TD. The Rel/NF-kappaB signal transduction pathway: introduction. Oncogene. 1999;18:6842-6844.

42. Barnes PJ, Karin M. Nuclear factor-kappaB: a pivotal transcription factor in chronic inflammatory diseases. $N$ Engl J Med. 1997;336: 1066-1071

43. Barnes PJ, Adcock IM. NF-kappa B: a pivotal role in asthma and a new target for therapy. Trends Pharmacol Sci. 1997;18:46-50.
44. Schreck R, Rieber P, Baeuerle PA. Reactive oxygen species intermediates as apparently widely used messengers in the activation of the NFKB transcription factor and HIV-1. EMBO J. 1991;10:2247-2258.

45. Henderson WR Jr, Chi EY, Teo JL, Nguyen C, Kahn M. A small molecule inhibitor of redox-regulated NF-kappa B and activator protein-1 transcription blocks allergic airway inflammation in a mouse asthma model. J Immunol. 2002;169:5294-5299.

46. Rahman I, MacNee W. Role of transcription factors in inflammatory lung diseases. Thorax. 1998;53:601-612.

47. Shang F, Gong X, Taylor A. Activity of ubiquitin-dependent pathway in response to oxidative stress. Ubiquitin-activating enzyme is transiently up-regulated. J Biol Chem. 1997;272:23086-23093.

48. Ginn-Pease ME, Whisler RL. Optimal NF- $\kappa$ B mediated transcriptional responses in Jurkat $\mathrm{T}$ cells exposed to oxidative stress are dependent on intracellular glutathione and costimulatory signals. Biochem Biophys Res Commun. 1996;226:695-702.

49. Stutz AM, Woisetschlager M. Functional synergism of STAT6 with either NF-kappa B or PU.1 to mediate IL-4-induced activation of IgE germline gene transcription. J Immunol. 1999;163:4383-4391.

50. Mori A, Kaminuma O, Mikami T, et al. Transcriptional control of the IL- 5 gene by human helper T cells: IL- 5 synthesis is regulated independently from IL-2 or IL-4 synthesis. J Allergy Clin Immunol. 1999; 103:S429-S436.

51. Lee YC, Lee KS, Park SJ, et al. Blockade of airway hyperresponsiveness and inflammation in a murine model of asthma by a prodrug of cysteine, L-2-oxothiazolidine-4-carboxylic acid. FASEB J. 2004; 18:1917-1919.

52. Schenk H, Klein M, Erdbrugger W, Dröge W, Schulze-Osthoff K. Distinct effects of thioredoxin and antioxidants on the activation of transcription factors NF-KB and AP-1. Proc Natl Acad Sci U SA. 1994; 91:1672-1676.

53. Jun DY, Chae HZ, Rhee SG, Jeang KT. Regulatory role for a novel human thioredoxin peroxidase in NF- $\mathrm{KB}$ activation. $J$ Biol Chem. 1997;27:30952-30961

54. Lin YL, Lin JK. (-)-Epigallocatechin-3-gallate blocks the induction of nitric oxide synthase by down-regulating lipopolysaccharide-induced

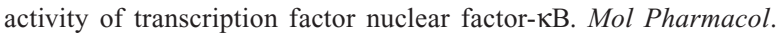
1997;52:465-672.

55. Verhasselt V, Vanden Berghe W, Vanderheyde N, Willems F, Haegeman G, Goldman M. N-acetyl-L-cysteine inhibits primary human T cell responses at the dendritic cell level: association with NF-kappaB inhibition. J Immunol. 1999;162:2569-2574.

56. Harper R, Wu K, Chang MM, et al. Activation of nuclear factor-kappa b transcriptional activity in airway epithelial cells by thioredoxin but not by N-acetyl-cysteine and glutathione. Am J Respir Cell Mol Biol. 2001;25:178-185.

57. Bhol KC, Schechter PJ. Effects of nanocrystalline silver (NPI 32101) in a rat model of ulcerative colitis. Dig Dis Sci. 2007;52:2732-2742.

58. Bhol KC, Alroy J, Schechter PJ. Anti-inflammatory effect of topical nanocrystalline silver cream on allergic contact dermatitis in a guinea pig model. Clin Exp Dermatol. 2004;29:282-287.

59. Bhol KC, Schechter PJ. Topical nanocrystalline silver cream suppresses inflammatory cytokines and induces apoptosis of inflammatory cells in a murine model of allergic contact dermatitis. Br J Dermatol. 2005;152:1235-1242.

60. Boucher W, Stern JM, Kotsinyan V, et al. Intravesical nanocrystalline silver decreases experimental bladder inflammation. J Urol. 2008;179:1598-1602.

61. Chen D, Xi T, Bai J. Biological effects induced by nanosilver particles. Biomed Mater. 2007;2:S126-S128.

62. Shin SH, Ye MK, Kim HS, Kang HS. The effects of nano-silver on the proliferation and cytokine expression by peripheral blood mononuclear cells. Int Immunopharmacol. 2007;7:1813-1818.

63. Kim SB, Ozawa T, Tao H, Umezawa Y. A proinflammatory cytokine sensor cell for assaying inflammatory activities of nanoparticles. Anal Biochem. 2007;362:148-150 
64. Gozal E, Ortiz LA, Zou XY, Burow ME, Lasky JA, Friedman M. Silica-induced apoptosis in murine macrophage: involvement of tumor necrosis factor- $\alpha$ and nuclear factor- $\mathrm{\kappa B}$ activation. Am J Respir Cell Mol Biol. 2002;27:91-98.

65. Kim JS, Kuk E, Yu KN, et al. Antimicrobial effects of silver nanoparticles. Nanomedicine. 2007;3:95-101.
66. Danilczuk M, Lund A, Saldo J, Yamada H, Michalik J. Conduction electron spin resonance of small silver particles. Spectrochim Acta A Mol Biomol Spectrosc. 2006;63:189-191.

67. Cha K, Hong HW, Choi YG, et al. Compariton of acute responses of mice livers to short-term exposure to nano-sized or micro-sized silver particles. Biotechnol Lett. 2008;30:1893-1899.

\section{Publish your work in this journal}

The International Journal of Nanomedicine is an international, peerreviewed journal focusing on the application of nanotechnology in diagnostics, therapeutics, and drug delivery systems throughout the biomedical field. This journal is indexed on PubMed Central, MedLine, CAS, SciSearch $®$, Current Contents $® /$ Clinical Medicine,
Journal Citation Reports/Science Edition, EMBase, Scopus and the Elsevier Bibliographic databases. The manuscript management system is completely online and includes a very quick and fair peer-review system, which is all easy to use. Visit http://www.dovepress.com/ testimonials.php to read real quotes from published authors.

Submit your manuscript here: http://www.dovepress.com/international-journal-of-nanomedicine-journal 